\title{
Review of Cross-Border E-Commerce and Directions for Future Research
}

\author{
Bidyut B. Hazarika, Western Michigan University, USA \\ Reza Mousavi, Western Michigan University, USA
}

\begin{abstract}
The emergence of cross-border e-commerce $(\mathrm{CBeC})$ has brought substantial changes to both businesses and consumers. Although $\mathrm{CBeC}$ businesses have existed for less than a decade, many academic researchers addressed important issues in this context. It is essential to evaluate what has been studied through a structured review of the literature and derive meaningful insights given that research on this topic is new and largely fragmented. Therefore, this study conducts a review of $\mathrm{CBeC}$ literature to find the current gaps and fragmentation to provide guidelines for future research. The review shows that research in this domain needs more attention and enforcement to address the current research gaps. Addressing the current gaps helps academia build a rigorous body of knowledge and enables practitioners to solve challenging business problems.
\end{abstract}

\section{KEYWORDS}

Barriers, Buyer Behavior, Cross-Border E-Commerce, Culture, Drivers, Framework, Literature Review, Trust

\section{INTRODUCTION}

Cross-border e-commerce $(\mathrm{CBeC})$ refers to an electronic business model where the customers and sellers are located in different countries or territories. Although trading activities are conducted on an online platform similar to traditional e-commerce platforms, there are several differences between $\mathrm{CBeC}$ and traditional e-commerce (Hsiao et al., 2017). These differences are in logistics, customs regulations, cybersecurity, customer relationship management, and payments. The volume of $\mathrm{CBeC}$ transactions has increased significantly in recent years. It is expected that by 2025 , the annual global revenues from $\mathrm{CBeC}$ would increase to 250 to 350 billion dollars (Valarezo et al., 2018). Online buyers worldwide are motivated by price advantage and diverse offerings to make purchases across borders. Although $\mathrm{CBeC}$ is growing rapidly worldwide, countries such as China and countries in the European Union (EU) are experiencing much faster growth than others. However, $\mathrm{CBeC}$ is complicated and risky because of the lack of legal enforcement across countries, cultural and language barriers, high information asymmetry, and high shipping cost (L. Wang et al., 2015). CBeC customers are different from traditional e-commerce customers due to differences in culture, language, habits, and expectations (T. Y. Kim et al., 2017). Despite these differences, an increased number of people use cross-border commerce because of the variety of benefits provided by $\mathrm{CBeC}$ (Valarezo et al., 2018).

To shed light on $\mathrm{CBeC}$ as an emerging e-business, many researchers explore this type of e-commerce from different angles. A significant portion of the literature is focused on drivers and 
barriers of $\mathrm{CBeC}$, such as infrastructures, regulations, culture, and communication (Gomez-Herrera et al., 2014). Areas such as buyers' behavior, cybersecurity and privacy, and trust have not been studied enough and therefore, there is an opportunity for future research to address these areas. To shed light on the current research status, this study reviewed the existing literature on the $\mathrm{CBeC}$. The focus of this review is to identify the major themes in the context of $\mathrm{CBeC}$ and provide a framework that explains the major factors contributing to $\mathrm{CBeC}$. It also aims to identify existing gaps in the literature and guide future research on addressing those gaps. Therefore, this study is set to answer three important questions:

1. Which aspects of $\mathrm{CBeC}$ have been examined in the existing research?

2. What are the major factors contributing to $\mathrm{CBeC}$ success?

3. What are the gaps that need to be addressed in the future?

The analysis of existing research shows that research on $\mathrm{CBeC}$ is fragmented. The majority of the research is focused on China and European Union countries. Other regions, such as America, Africa, and the Middle East, have not received considerable attention. In addition to geographical areas, logistics have not received much attention. The review also shows that e-commerce has grown significantly and continues to grow. Companies operating under the traditional form of business have to consider switching to e-commerce as an increasing number of people now purchase their products online. There is also the need for countries to put in place supportive policies and infrastructure to promote $\mathrm{CBeC}$. The results from this study reveal that the individual country's policies play a considerable role in $\mathrm{CBeC}$ through the policies it develops and the infrastructure it puts in place. Lastly, there is a need for e-commerce firms to develop marketing strategies that would influence consumer attitudes and purchase intention in the market. There is a need to cultivate trust among consumers about the authenticity of online vendors' products. This will help increase the intention to purchase among consumers in the market.

We also present a framework that can explain and classify the current body of knowledge for a thorough evaluation of the state of $\mathrm{CBeC}$ research. Such an analysis contributes to research and has great implications for the practice. This study's findings provide a guideline for future researchers to determine the existing trend of the $\mathrm{CBeC}$ research domain and address the current gaps. Furthermore, the classification and analysis of the literature can provide researchers with a standard taxonomy that can enhance collaboration among researchers who know different areas that contribute to $\mathrm{CBeC}$ (e.g., supply chain, consumer behavior, analytics, and foreign trade regulations).

In brief, $\mathrm{CBeC}$ has emerged as a significant force in the business environment, meaning that businesses have to pay significant attention. The growth in cross-border and e-commerce, in general, is likely to have been influenced by technological development. With the emergence of the internet, people can easily order goods online. On the other hand, with increased levels of globalization, there is increased trade cooperation among countries, which is likely to have contributed to the growth of $\mathrm{CBeC}$. Finally, e-commerce firms must put in place strategies that would positively influence consumers in terms of attitude and trust.

\section{LITERATURE IDENTIFICATION AND COLLECTION}

This study employs a systematic approach to identify relevant studies for the literature review (Cheung \& Thadani, 2012). We used two methods to collect academic and peer-reviewed journal articles and conference proceedings. In the first method, they searched various academic databases, including Web of Science, Business Source Premier, Science Direct, ABI/INFORM Global (ProQuest), Emerald, and Wiley Online Library. They used different keywords, such as "cross-border e-commerce," "CBeC," "global e-commerce," "cross border logistics," "cross-border business," and "cross-border selling" to 
identify potentially relevant articles. In the second phase, we performed a backward-forward search (Levy \& Ellis, 2006) manually using Google Scholar to identify studies that cite the selected primary studies. Doing this helped to make sure that the search is comprehensive and relatively complete (Webster \& Watson, 2002).

The search yielded 63 articles using the previously defined keywords. Most of these articles were relevant to the research subject. After refining the sample of collected articles and removing irrelevant studies from the sample, we ended up with a total of 40 peer-reviewed articles published between 2014 and 2020 remained. Appendix A provides a summary of the collected articles.

\section{REVIEW OF THE LITERATURE}

To guide the review of the research articles on $\mathrm{CBeC}$, we performed a careful examination of existing literature reviews in the context of $\mathrm{CBeC}$. Giuffrida et al. (2017) performed the only literature review performed on $\mathrm{CBeC}$ in Greater China and the role of logistics. In their work, we classified each article into four main topics: main features of the article (year of publication, name of the journal, name, and nationality of authors), methods used in the paper, main themes, and geographical focus.

We decided to build on this paper and expand the review by examining $\mathrm{CBeC}$ across various world regions. In addition to the topics, research methods, and themes used in the previous works, the authors focus on drivers and barriers to $\mathrm{CBeC}$, buyer behavior, trust, and culture. They investigate culture as a separate theme from drivers and barriers to $\mathrm{CBeC}$ because researchers have suggested acculturation as a critical factor that affects CBeC (e.g., Lacka \& Yip, 2018). The papers were grouped together into different clusters based on the following research themes: logistics, institutional/ government structures, cybersecurity and privacy, consumer behavior, and culture. Doing this helped categorize each article's contributions, identify and discuss key topics, existing research gaps, and provide suggestions for future research in $\mathrm{CBeC}$.

\section{RESEARCH METHODOLOGY}

Different methodologies such as analytical model, case study, survey, empirical, secondary data, interviews, conceptual model, narrative analysis, panel data, literature review, general review, and topic modeling were used. The variety of methodologies used shows that researchers from different disciplines and diverse expertise studied this topic. Although looking at this topic from different angles and using different methodologies seem favorable, the current body of knowledge about $\mathrm{CBeC}$ is still very limited. The reason is that research methodologies and focused are scattered, and there is no integrated view of any aspects of $\mathrm{CBeC}$.

Survey-based research was the most frequently used methodology in the pool of collected articles. Therefore, the authors focus on evaluating this type of methodology in the pool of studies. The literature review showed that the sample size ranged from 118 to 678 (mean $=379$ ). The majority of survey-based research used Partial Least Squares path modeling instead of structural equation modeling (SEM) to evaluate their measurement and structural models.

Of all the articles published in $\mathrm{CBeC}$, most focused on Asia, followed by the USA and the European Union. China was the most significant focus of researchers. They addressed different aspects of e-commerce, including drivers, barriers of $\mathrm{CBeC}$, strategies used by businesses, and purchase intention among consumers. There are several reasons why China is the main focus in the majority of the studies. One of them is that China has emerged as a significant player in the world economy and trade. With its huge population, the country presents an attractive market for firms. With e-commerce developing rapidly in the country, researchers are interested in understanding the factors that promote it, the possible barriers to $\mathrm{CBeC}$, the policies that have been adopted, and their effectiveness. For example, in their study, Ma et al. (2018) examine the rise of cross-border exports in China. They note that $\mathrm{CBeC}$ has grown significantly in China, meaning that there are unique 
advantages within China that have contributed to the growth. In their study, they established that the e-commerce industry had substantial growth. The industry had a generally stable situation where logistics facilitation is involved but the rather fluctuating situation in customs facilitation. Moreover, the e-commerce industry has shifted gradually to competing for more efficient and cheaper marketing channels and techniques, and the industry has seen a rise in the risk magnitude.

Jin et al. (2019) established that while e-commerce has grown significantly in China, with it being a priority by the government and other players, the development of low-cost and efficient transportation of $\mathrm{CBeC}$ import and export goods is still in the early stages. The study shows that while e-commerce has grown significantly and rapidly in China, it has not developed well due to shortcomings in policy, government action, and infrastructure.

The significant focus on the USA is probably due to it being a significant market. The USA is the largest economy in the world by nominal GDP. On the other hand, it has significantly developed e-commerce. With technological development, e-commerce has been adopted by many businesses in the USA. A closer examination of the studies that focused on the USA shows that they are not exclusive to one location but include others, such as Korea and China. In fact, most of the studies involve both China and the USA. This may be a testament to the significance of the two countries in the world economy. On the other hand, it shows where researchers tend to concentrate their studies. With most studies focused on the two nations, it shows researchers' desire from the two nations to explore $\mathrm{CBeC}$ in the nations and possibly inform policymakers and businesses on how to best approach the subject from a practical point of view.

The studies on the European Union countries examine the drivers and impediments of $\mathrm{CBeC}$ in the EU. The focus on the whole region, as opposed to a single country, provides insight into how well $\mathrm{CBeC}$ has developed globally, the factors that have contributed to its growth, the factors that hinder its development, and what should be done to ensure $\mathrm{CBeC}$ is improved. The focus on a region also helps determine the similarities and differences among individual countries and how they contribute to or hinder the development of $\mathrm{CBeC}$ in a region.

\section{DRIVERS AND BARRIERS TO CBEC}

Drivers and barriers are addressed mainly by two articles. Gomez-Herrera et al. (2014) provide a macro-level overview of major drivers and barriers to $\mathrm{CBeC}$. Their analysis is based on a single EU consumer survey data set that offers some unique insights into the value and direction of online cross-border trade between EU countries. They identified that cost could be a driver and barrier to $\mathrm{CBeC}$. The cost of purchasing products across the border influences e-commerce. If the cost is high, people are discouraged from buying from other regions and vice versa (Gomez-Herrera et al., 2014). Home bias refers to customers' natural preference for home market products, which may impede $\mathrm{CBeC}$ growth. In their study, Gomez-Herrera et al. (2014) found that online trade was more biased toward home market products than offline trade. They also argued that language barriers increase with online trading, and this acts as another impediment to $\mathrm{CBeC}$. Language, depending on consumers, can be a driver or barrier to $\mathrm{CBeC}$. The authors found that shared language between trading partners motivates customers to shop. Therefore, countries where people speak the same language, are more likely to perform $\mathrm{CBeC}$ trades. The policymakers' actions can act as a driver or barrier to $\mathrm{CBeC}$. For example, policymakers can promote $\mathrm{CBeC}$ by increasing the interoperability and compatibility of online payment systems between countries to facilitate cross-border online trade.

In contrast with Gomez-Herrera et al. (2014), Valarezo et al. (2018) provide a micro-level overview of factors that contribute to $\mathrm{CBeC}$. They identify customers' gender, education, and computer and internet skills as drivers or barriers to $\mathrm{CBeC}$. In their study, Valarezo et al. (2018) found that males are more likely to engage in $\mathrm{CBeC}$ than females. They also found that education significantly contributes to $\mathrm{CBeC}$ adoption in $\mathrm{EU}$ countries since educated people are more likely to be aware of $\mathrm{CBeC}$ and its advantages. Lastly, they suggested customers' computer and internet skills as drivers of $\mathrm{CBeC}$. 
More computer and internet skills enable people to gain information about $\mathrm{CBeC}$ operations and make online purchases successfully.

The main drivers identified include education, computer skills, policymakers, and e-commerce systems' interoperability among countries. These factors can also be barriers, depending on their characteristics ( $\mathrm{Li} \& \mathrm{Li}, 2019$ ). For example, less educated individuals are unlikely to engage in $\mathrm{CBeC}$ because they do not have the knowledge and skills to carry out the process. It is the same situation with individuals with limited computer skills. On the other hand, a country's policies determine whether e-commerce would be supported in a particular market. Also, information technology influences CBeC. According to Han \& Kim (2019), information technology infrastructures play a critical role in consumer informedness, promoting $\mathrm{CBeC}$. It shows that information technology is a key driver of $\mathrm{CBeC}$.

A close examination of the studies on the drivers and barriers shows that there is more focus on the external factors that influence $\mathrm{CBeC}$ when compared to internal factors. Usually, the performance of a firm in the market depends on the internal and external factors. The internal factors comprise the competencies the firm has to take advantage of the market opportunities effectively. In the case of $\mathrm{CBeC}$, it involves the firm's ability to effectively serve customers with different characteristics as well as avail products to them in the right quantity and quality and at the desired time. It also involves the firm's ability to adapt to different consumer characteristics, and thereby satisfying varied consumer needs. The internal competencies in a firm determine whether it will easily adapt to the market, appeal to consumers, and attract them to its products (Song et al., 2019). The internal environment is as significant as the external one.

\section{Buyer Behavior}

Consumer behavior in relation to $\mathrm{CBeC}$ has been addressed in the literature. $\mathrm{CBeC}$ is considered a subset of e-commerce. $\mathrm{CBeC}$ refers to the online trade from business to business (B2B), business to consumer (B2C), and consumer to consumer $(\mathrm{C} 2 \mathrm{C})$. But, in $\mathrm{CBeC}$, there is no online consumer to business ( $\mathrm{C} 2 \mathrm{~B})$ trade like traditional e-commerce. Hence, consumer behavior in $\mathrm{CBeC}$ is similar to traditional e-commerce. For instance, dysfunctional customer behavior, consumer attitude and how it influences purchase intention in $\mathrm{CBeC}$, the effect of consumer intention to engage in $\mathrm{CBeC}$, and the influence of $\mathrm{CBeC}$ platform quality on consumer purchase intention are among the consumer-related factors that have been studied (Ying Wang et al., 2019). Dysfunctional customer behavior refers to "an aberrant customer behavior in exchange settings that violates the generally accepted norms of conduct in such a way that it is held in disrepute by marketers and most customers, and deviates from normal customer behavior" (Lin et al., 2018). Lin et al. (2018) found that service dissatisfaction and negative emotion induce dysfunctional customer behavior. If customers do not receive the expected quality of services or products when they engage in online shopping, they are likely to exhibit negative emotions (Lin et al., 2018). They find that distributive justice is particularly important in online shopping. Then customers perceive that there is no fairness in the way they have been treated; they exhibit negative emotions and become dissatisfied. The results imply that the quality of products or services determines the customers' attitude and how they perceive the services or products.

The literature also addresses purchase intention and the factors that influence also effect $\mathrm{CBeC}$. One of the investigated factors is consumer attitude and its relationship with purchase intention. For instance, consumer attitudes and beliefs, such as beliefs about electronic service quality, their need for uniqueness, and beliefs about perceived behavioral control have been studied (B. Han et al., 2018). The findings showed that the belief about electronic service quality and consumers' need for uniqueness positively affects consumer attitude toward purchasing online, which positively influences purchase intention. This implies that the intention to buy from international online stores is determined by the kind of attitude an individual has toward online shopping as a whole and how they perceive the quality of products and services (B. Han et al., 2018). If a consumer perceives the quality of online products as inferior, they are unlikely to buy them. On the other hand, the ability 
of e-commerce to appeal to a consumer's need for uniqueness determines whether it would motivate them to purchase from them. Similarly, platform situational and platform enduring involvement has a positive effect on trust. On the other hand, trust influences consumers' purchase intention (Xiao et al., 2019). It implies that consumers' knowledge and awareness about a product are key to consumer purchase intention in $\mathrm{CBeC}$.

Price incentives are major consumer motives for online purchases (S. Huang \& Chang, 2017). People are motivated to make online purchases because the price is favorable compared to offline trade. On the other hand, a high level of product uniqueness motivates consumers to make purchases. Combining favorable pricing with product uniqueness provides e-commerce vendors with a competitive advantage in the market and allows them to sell across the border. On the other hand, the waiting cost is a significant inhibitor to purchase intention (S. Huang \& Chang, 2017). A longer wait time discourages consumers from making purchases from an international e-commerce vendor. This implies that if an e-commerce vendor wants to increase sales across the border, they must improve their logistics to reduce the waiting time. Lastly, the legal system and reputation of a vendor's country, according to Huang \& Chang (2017), determines the level of trust that consumers have in a vendor. While a firm may have the right product, an efficient distribution network, and communicate well with consumers in the market, the vendor's country's bad reputation may discourage consumers from buying from the vendor.

\section{Trust}

According to Guo et al. (2018), research has focused entirely on addressing the buyer's trust, while very few studies have addressed seller trust. Sellers are frequently at the risk of chargeback fraud when a buyer disputes a transaction and asks for their money to be refunded. In their study, Guo et al. (2018), focus on factors that influence sellers' trust. They establish that some of the factors influencing seller trust include perceived national integrity and seller protection mechanisms. Perceived national integrity refers to the social norms that adhere to moral and ethical principles; buyers from a country with high integrity would be expected to follow social rules and customs, which prevent them from engaging in opportunism (Doney et al., 1998). The perceived national integrity of the buyer's country determines whether a seller trusts the buyer. A higher perceived national integrity increases the level of trust in the seller and lowers the risk of chargeback fraud. According to Guo et al. (2018), the country of origin sends signals to the seller about the seller's trustworthiness. On the other hand, if the seller perceives the seller protection mechanism as effective, their level of trust increases, making them more willing to engage in cross-border commerce.

Cui et al. (2019) found that $\mathrm{CBeC}$ is influenced by buyers' and sellers' trust. For a transaction to take place, there must be mutual trust between the seller and the buyer. Thus, if either party does not trust the other, it is unlikely for a transaction to occur. On the other hand, while the seller may not trust the buyer, if the seller protection mechanism is effective, the seller may be willing to take part in a transaction since they are protected from chargeback fraud (Cui et al., 2019). When the seller protection mechanism is not very effective, the seller may not be willing to risk selling to a buyer they do not trust.

\section{Culture}

Culture is also an aspect of $\mathrm{CBeC}$ addressed in the literature. Lacka \& Yip (2018) observed that while e-commerce has grown significantly over time, the growth is not shared by all the EU states, and culture is one reason for this difference. This study examines the effect of acculturation on e-commerce. Acculturation is "the general process of movement and adoption to the consumer cultural environment in one country by persons from another country" (Peñaloza, 1994, p. 33). Lacka \& Yip (2018) found that the acculturation process affects consumer attitudes toward e-commerce. Specifically, subjective norms and perceived behavioral control can easily be adopted. Examining this information about $\mathrm{CBeC}$ implies that culture can be a barrier to $\mathrm{CBeC}$, especially if e-commerce is not embraced in a 
particular culture. Therefore, it compels an e-commerce vendor or company to engage in acculturation to change consumers' attitudes about e-commerce to encourage purchases.

Like e-commerce, all transactions in $\mathrm{CBeC}$ between the buyer and the seller happen through an online platform. Thus, it would be interesting to see how a country's culture impacts the adaptation of an online platform by a consumer in a different country. Hofstede et al.'s (1984) cultural dimensions framework is a valuable framework that can be used for web analysis, advertising, and web content development. The six cultural dimensions proposed by Hofstede were first operationalized by Singh et al. (2003) and later revised and updated (Singh, Zhao, et al., 2005) to comprise six dimensions (Collectivism, Uncertainty Avoidance, Power Distance, Individualism, High Context, and Low Context). Singh and his colleagues used the framework to study American companies' adaptation of domestic and Chinese websites. They state that "the web is not a culturally neutral medium, but it is full of cultural markers that give country-specific websites a look and feel unique to the local culture" (Singh et al., 2003, p. 63). Similar results were found in studies that compared Chinese, Indian, Japanese, and US websites (Singh, Zhao, et al., 2005) and websites from the US, France, and Germany (Singh, Kumar, et al., 2005). Mooji (1998) states that there might be global products and brands, but there are no global people. She found that even though consumers might buy the same products, cultural values, and motives to buy products differ. Therefore, $\mathrm{CBeC}$ companies should tailor their online content to sell products and develop creative strategies to attract consumers based on the cultural aspect of the buyer country. This way, companies involved in $\mathrm{CBeC}$ would be able to capture larger online audiences.

\section{RESEARCH THEMES}

Clustering is the process of grouping the population into small groups with similar themes. The authors clustered the articles based on different research themes: logistics, institutional/government structures, cybersecurity and privacy, consumer behavior, and culture. Culture, cybersecurity, and privacy have received limited attention. Other research did not fall under any of the selected clusters and instead focused on cost and globalization. The majority of the articles focused on logistics, institutional/ government, and consumer behavior; it shows that these three elements are the most important factors in $\mathrm{CBeC}$. For example, logistics is key because it determines whether products can be availed to the market in time. As such, while an organization may have a well-developed e-commerce structure, poor logistics would hamper its ability to engage in $\mathrm{CBeC}$ (Hsiao et al., 2017).

On the other hand, the institutional and government structures are key determinants of the success of $\mathrm{CBeC}$. For institutional structures, it involves having a system that promotes e-commerce, including an online ordering system, personnel to handle online orders, and transport equipment to deliver the products to customers in the market. For government structures, policies and relevant infrastructure, such as a transport system, allow firms to deliver products in the market (J. Huang, 2017). For example, as observed in China's case, the lack of relevant infrastructure makes it hard for $\mathrm{CBeC}$ to be promoted irrespective of the existing policies.

Lastly, consumer behavior is key to $\mathrm{CBeC}$ because the ultimate goal of e-commerce is to sell products to consumers. Therefore, it implies that the attitude consumers have toward e-commerce, in general, is crucial. As demonstrated in some studies, there are many cases where consumers have a poor attitude toward e-commerce, which makes them less enthusiastic about engaging in it (Zhu et al., 2019).

While culture and cybersecurity and privacy have not received significant attention, they are important in $\mathrm{CBeC}$. Culture is an important determinant of consumer behavior and attitude, which, in turn, influences the purchase intention. The culture in which individuals operate in influences how they view their world and every item. For example, similar food is treated differently by different cultures, determining people's attitudes within these cultures towards food. Thus, knowledge of a 
region's cultural characteristics is important in deciding whether e-commerce is likely to be embraced or rejected and what needs to be done to change the cultural attitude toward it (Zhao, 2018).

On the other hand, e-commerce characteristics are tied to online transactions and payment, so the issue of cybersecurity and privacy emerges as a significant problem (Zhong et al., 2020). With consumers compelled to surrender their personal information during transactions such as names, location, and bank accounts to facilitate payment, their privacy is put at risk, and such information can fall into unintended individuals' hands (Shi et al., 2020). Conversely, with almost all transactions taking place online, there is always the threat of cyberattacks. A firm's online system can be hacked, and crucial information can be taken from it or sabotaged (Polanski, 2015). This can hinder the firm's ability to deliver goods to customers effectively. Thus, these two areas need more attention from researchers.

\section{PROPOSED FRAMEWORK, CONTRIBUTIONS, AND FUTURE DIRECTIONS}

\section{Framework}

A framework and taxonomy that can explain and classify the current body of knowledge would be useful for a thorough evaluation of the state of $\mathrm{CBeC}$ research. Such an analysis contributes to research and has significant implications for practice. This study's findings provide guidelines for future researchers to find the existing trend of the $\mathrm{CBeC}$ research domain and address the current gaps. Furthermore, the classification and analysis of the literature can provide researchers with a standard taxonomy that can enhance collaboration among researchers who are knowledgeable in different areas that contribute to $\mathrm{CBeC}$ (e.g., supply chain, consumer behavior, analytics, and foreign trade regulations).

Based on our review of the literature, we came up with a framework that presents the findings of the literature on $\mathrm{CBeC}$ (See Figure 1). $\mathrm{CBeC}$ was studied from two different but related levels. Macro and micro level. In the macro-level view, the majority of studies focus on four major groups of factors that cause success or failure on CBeCs. These four groups include cultural values and population demographics, communication, monetary costs, and macro-level policies and control mechanisms. Another group of studies investigates $\mathrm{CBeC}$ at a micro-level. These researchers focus on customers, sellers, and $\mathrm{CBeC}$ platform characteristics that affect a single customer purchasing decision. We grouped these micro-level factors into three major groups: customer's past experience, characteristics of $\mathrm{CBeC}$ platform and products, customer' beliefs/attitudes/characteristics.

The proposed framework provides an overview of the current body of knowledge in $\mathrm{CBeC}$ that could help us answer the research questions this study aims to address. Our literature review and the proposed framework portraits a big picture of the goals and findings of the $\mathrm{CBeC}$ studies, which addresses the first research question of this study. Moreover, the summary table in Appendix A supports the framework and summarizes the $\mathrm{CBeC}$ studies' characteristics such as level of analysis, methodology, theory, geographical focus, and findings. The framework also addresses this study's second research question by summarizing the factors contributing to the $\mathrm{CBeC}$ success in macro and micro-levels. The framework helps us represent a summary of the fragmented and unmatured $\mathrm{CBeC}$ literature and implicitly guides us to identify research gaps and opportunities for future researchers. We summarize these gaps and opportunities in the gaps and research opportunities section.

\section{Discussion and Contributions}

Our study has several contributions to academia and practice. First, this study used a systematic literature review method to identify $\mathrm{CBeC}$ related studies and summarize them. This summary could help future $\mathrm{CBeC}$ researchers identify the research areas, methodologies, and populations studied in the past and propose research questions to address the gaps and unanswered questions. Second, the proposed framework and review identify a significant issue in the body of knowledge. 
The reviewed studies do not follow any research stream, and therefore, most of the studies are not built upon the previous research findings. This issue suggests a need to evaluate current literature and propose guidelines by encouraging literature review studies and calling for papers in this area. The Journal of Global Information Management's (JGIM) special issue on Sharing Economy and $\mathrm{CBeC}$ is a great effort to build a strong and well-defined research guideline in this area of research. The proposed framework also creates a precise overview and proposes a structure for the $\mathrm{CBeC}$ literature by categorizing existing literature into macro and micro levels studies. In the next section, we explain how this study's findings could guide future research to expand the body of knowledge in this fast-evolving area.

This study addresses various aspects of cross-border e-commerce. While the highlighted themes are some of the issues addressed, $\mathrm{CBeC}$ in totality, go beyond these themes. The four main requirements are business and market knowledge, analytical ability, technical skills, and practical business ability. Our findings show that the knowledge and skills possessed by an e-commerce firm's workforce are keys to its performance.

The issues addressed in the existing literature include the general development of cross-border, drivers and barriers to $\mathrm{CBeC}$, the influence of logistics and regulatory environment on $\mathrm{CBeC}$, consumer trust, consumers' experiences in online shopping and factors that influence consumer purchase intention in $\mathrm{CBeC}$. With the studies on drivers and barriers to $\mathrm{CBeC}$, mainly focusing on the external factors, they fail to acknowledge the role e-commerce plays in promoting cross-border trade. We observed that even though the government may put in place the right policies to promote $\mathrm{CBeC}$ and might even develop the right infrastructure if a firm does not have the right competencies to handle $\mathrm{CBeC}$ it would be difficult for it to realize high trade potential.

Concerning the general development of cross-border, there is evidence that $\mathrm{CBeC}$ has developed significantly over time. It has emerged as a significant force in the business environment, meaning that businesses have to pay significant attention to it. The growth in $\mathrm{CBeC}$ and e-commerce, in general, is likely to have been influenced by technological development. With the emergence of the internet, people can easily order goods online. On the other hand, with increased levels of globalization, there is increased trade cooperation among countries, which have contributed to the growth of $\mathrm{CBeC}$. We concluded that logistics is an essential determinant of $\mathrm{CBeC}$ and is dependent on more than one nation for it to be promoted. For example, if one nation does not have the right logistics infrastructure in place, it is hard for $\mathrm{CBeC}$ trade to happen if the other country does not have the right logistics infrastructure.

Finally, this study provides contributions for practitioners by offering a framework that represents the macro and micro level success factors for $\mathrm{CBeC}$. $\mathrm{CBeC}$ vendors can apply the framework to increase their profit and customer satisfaction bases on the identified success factors. Vendors also benefit from our findings by investigating solutions for issues such as home bias, communication issues, tariffs, and communication costs as major barriers for $\mathrm{CBeC}$.

\section{Future Research Directions}

Our literature review and proposed framework enable us to highlight some opportunities for future research. First, our literature review identifies a wide range of factors contributing to $\mathrm{CBeC}$ adoption and success or failure. Many of these factors were only studied once (See Figure 1 and Appendix A), which shows that the emerging $\mathrm{CBeC}$ literature is fragmented. Therefore, future research is supposed to identify the key factors and provide strong empirical support for these key factors' significance. One major direction for future research is investigating key characteristics of $\mathrm{CBeC}$ and its vendors that support $\mathrm{CBeC}$ success. The other area, which is disjointed and needs attention is customer behavior in $\mathrm{CBeC}$. The findings can be essential for academia and practice because one of the major differences between $\mathrm{CBeC}$ and traditional e-commerce is that $\mathrm{CBeC}$ customers are different in terms of culture, language, etc. These differences could significantly impact customers' behavior. The existing literature does not provide a comprehensive understanding of the key factors related to $\mathrm{CBeC}$ customers' behavior and differences between customers' behavior on $\mathrm{CBeC}$ and traditional e-commerce. 
Second, this study shows that many theories have been adopted to study $\mathrm{CBeC}$. Although studying $\mathrm{CBeC}$ from different perspectives could enhance our understanding, it could also prevent researchers from studying $\mathrm{CBeC}$ from new angles. Because $\mathrm{CBeC}$ is a new and fast-evolving field of research, existing theories may not offer accurate and complete understandings. Therefore, future researchers could use exploratory research designs to offer a more accurate and comprehensive understanding of the key factors in $\mathrm{CBeC}$. Descriptive and predictive methodologies can be applied to the available data on different aspects of $\mathrm{CBeC}$ (e.g., supply chain, customer behavior) to explore and generate new theories and compare them with previous theories in similar contexts (e.g., e-commerce, social-commerce). Exploring $\mathrm{CBeC}$ from different angles (applying other existing theories or generating new theories) not only contributes to the $\mathrm{CBeC}$ literature by offering new theories that explain $\mathrm{CBeC}$ dynamics but also help $\mathrm{CBeCs}$ to apply $\mathrm{CBeC}$-specific theories to become more efficient and profitable.

Third, our framework shows that $\mathrm{CBeC}$ studies could be divided into two major categories: macro and micro-level factors that affect $\mathrm{CBeC}$ or its customers' purchase decisions. However, the inter-relationships among the macro and micro level factors have not been studied in the literature. Some examples are inter-relationships among tariffs and price incentives or macro-level policies and customers' attitudes and trust. Uncovering these inter-relationships could uncover the existing interactions among macro and micro-level factors and their impacts on the key stakeholders in $\mathrm{CBeC}$ context Finally, future research needs to study the impact of $\mathrm{CBeC}$ on the eco-system of international trades (e.g., international trades, tariffs, imports and exports). The findings could be insightful for the $\mathrm{CBeC}$, governments and other major stakeholders in $\mathrm{CBeC}$ context.

Few critical research questions that future research on $\mathrm{CBeC}$ can address are: "what are the key factors that contribute to $\mathrm{CBeC}$ at macro and micro levels?", "how do different research designs contribute to the understanding $\mathrm{CBeC}$ dynamics by proposing new theories and insights?", "how do the proposed theories explain the difference between $\mathrm{CBeC}$ and traditional e-commerce?", "how do major macro and micro-level factors in $\mathrm{CBeC}$ impact each other?", and "how does $\mathrm{CBeC}$ affect the eco-system of international trades? How do these impacts influence different stakeholders?".

\section{Limitations and Conclusion}

Like other literature review studies, this study has some limitations. One limitation of this study is that our findings are subject to the pool of peer-reviewed articles that meet our selection criteria. Because $\mathrm{CBeC}$ literature is still evolving, future literature review studies could enlarge the pool of articles and elicit more insights about $\mathrm{CBeC}$ in the future. In this case, future studies could achieve a complete understanding of how $\mathrm{CBeC}$ impacts consumers, businesses, and governments. Another limitation is that although the search for articles was intended to cover all relevant topics to $\mathrm{CBeC}$, most of the retrieved literature focuses on logistics. If future research focuses on other aspects of $\mathrm{CBeC}$ (e.g., the research questions were suggested in the previous section), other important $\mathrm{CBeC}$ research topics will be addressed.

We reviewed both the scholarly and practical literature to identify the limitations in each area. Based on these results, we provide high-level research agendas for future $\mathrm{CBeC}$. We do not offer definitive research questions but, rather, illustrate how researchers can examine and understand different aspects of $\mathrm{CBeC}$ in the future. We hope this review will provide researchers with a foundation to study this important phenomenon. Finally, $\mathrm{CBeC}$ has been developed significantly over time. A review of studies selected for this paper shows that cross-border e-commerce has grown significantly in China and several other East Asian countries. 


\section{REFERENCES}

Aulkemeier, F., Iacob, M. E., \& van Hillegersberg, J. (2017). An architectural perspective on service adoption: A platform design and the case of pluggable cross-border trade compliance in e-commerce. Journal of Organizational Computing and Electronic Commerce, 27(4), 325-341. doi:10.1080/10919392.2017.1363588

Baek, E., Lee, H. K., \& Choo, H. J. (2019). Cross-border online shopping experiences of Chinese shoppers. Asia Pacific Journal of Marketing and Logistics, 32(2), 366-385. doi:10.1108/APJML-03-2018-0117

Cheng, X., Su, L., \& Zarifis, A. (2019). Designing a talents training model for cross-border e-commerce: A mixed approach of problem-based learning with social media. Electronic Commerce Research, 19(4), 801-822. doi:10.1007/s10660-019-09341-y

Cheung, C. M. K., \& Thadani, D. R. (2012). The impact of electronic word-of-mouth communication: A literature analysis and integrative model. Decision Support Systems, 54(1), 461-470. doi:10.1016/j.dss.2012.06.008

Cho, H., \& Lee, J. (2017). Searching for logistics and regulatory determinants affecting overseas direct purchase: An empirical cross-national study. Asian Journal of Shipping and Logistics, 33(1), 11-18. doi:10.1016/j. ajs1.2017.03.002

Cui, Y., Mou, J., Cohen, J., \& Liu, Y. (2019). Understanding information system success model and valence framework in sellers' acceptance of cross-border e-commerce: A sequential multi-method approach. Electronic Commerce Research, 19(4), 885-914. doi:10.1007/s10660-019-09331-0

Deng, Z., \& Wang, Z. (2016). Early-mover advantages at cross-border business-to-business e-commerce portals. Journal of Business Research, 69(12), 6002-6011. doi:10.1016/j.jbusres.2016.05.015

Doney, P. M., Cannon, J. P., \& Mullen, M. R. (1998). Understanding the influence of national culture on the development of trust. Academy of Management Review, 23(3), 601-620. doi:10.5465/amr.1998.926629

Giuffrida, M., Mangiaracina, R., Perego, A., \& Tumino, A. (2017). Cross-border B2C e-commerce to Greater China and the role of logistics: A literature review. International Journal of Physical Distribution \& Logistics Management, 47(9), 772-795. doi:10.1108/IJPDLM-08-2016-0241

Gomez-Herrera, E., Martens, B., \& Turlea, G. (2014). The drivers and impediments for cross-border e-commerce in the EU. Information Economics and Policy, 28(1), 83-96. doi:10.1016/j.infoecopol.2014.05.002

Guo, Y., Bao, Y., Stuart, B. J., \& Le-Nguyen, K. (2018). To sell or not to sell: Exploring sellers' trust and risk of chargeback fraud in cross-border electronic commerce. Information Systems Journal, 28(2), 359-383. doi:10.1111/isj.12144

Hair, J. F., Risher, J. J., Sarstedt, M., \& Ringle, C. M. (2019). When to use and how to report the results of PLSSEM. European Business Review, 31(1), 2-24. doi:10.1108/EBR-11-2018-0203

Han, B., Kim, M., \& Lee, J. (2018). Exploring consumer attitudes and purchasing intentions of cross-border online shopping in Korea. Journal of Korea Trade, 22(2), 86-104. doi:10.1108/JKT-10-2017-0093

Han, J. H., \& Kim, H. M. (2019). The role of information technology use for increasing consumer informedness in cross-border electronic commerce: An empirical study. Electronic Commerce Research and Applications, 34(January), 100826. doi:10.1016/j.elerap.2019.100826

He, Y., \& Wang, J. (2019). A panel analysis on the cross border e-commerce trade: Evidence from ASEAN countries. Journal of Asian Finance. Economics and Business, 6(2), 95-104. doi:10.13106/jafeb.2019.vol6.no2.95

Hoehle, H., Scornavacca, E., \& Huff, S. (2012). Three decades of research on consumer adoption and utilization of electronic banking channels: A literature analysis. Decision Support Systems, 54(1), 122-132. doi:10.1016/j. dss.2012.04.010

Hofstede, G., \& Bond, M. H. (1984). Hofstede's culture dimensions: An independent validation using Rokeach's value survey. Journal of Cross-Cultural Psychology, 15(4), 417-433. doi:10.1177/0022002184015004003

Hsiao, Y. H., Chen, M. C., \& Liao, W. C. (2017). Logistics service design for cross-border E-commerce using Kansei engineering with text-mining-based online content analysis. Telematics and Informatics, 34(4), 284-302. doi:10.1016/j.tele.2016.08.002 
Huang, J. (2017). Comparison of e-commerce regulations in Chinese and American ftas: Converging approaches, diverging contents, and polycentric directions? Netherlands International Law Review, 64(2), 309-337. doi:10.1007/s40802-017-0094-1

Huang, S., \& Chang, Y. (2017). Factors that impact consumers' intention to shop on foreign online stores. Proceedings of the 50th Hawaii International Conference on System Sciences, 3981-3990. doi:10.24251/ HICSS.2017.481

Huang, S. L., \& Chang, Y. C. (2019). Cross-border e-commerce: Consumers' intention to shop on foreign websites. Internet Research, 29(6), 1256-1279. doi:10.1108/INTR-11-2017-0428

Jin, F., Yan-Ling, C., Xiao-Jun, J., \& Liang, Z. (2019). An observation on China comprehensive pilot areas for cross-border E-commerce in Henan Province. Procedia Manufacturing, 30, 77-82. doi:10.1016/j. promfg.2019.02.012

Khan, G. F., Sarstedt, M., Shiau, W.-L., Hair, J. F., Ringle, C. M., \& Fritze, M. P. (2019). Methodological research on partial least squares structural equation modeling (PLS-SEM). Internet Research, 29(3), $407-429$. doi:10.1108/IntR-12-2017-0509

Kim, H., \& Lee, H. (2016). Asset specificity and capability of e-Trade performance: Evidence from Korea. Journal of Korea Trade, 20(1), 2-20. doi:10.1108/JKT-03-2016-001

Kim, T. Y., Dekker, R., \& Heij, C. (2017). Cross-border electronic commerce: Distance effects and express delivery in European Union markets. International Journal of Electronic Commerce, 21(2), 184-218. doi:10. 1080/10864415.2016.1234283

Lacka, E., \& Yip, N. K. T. (2018). Revealing the effect of acculturation process on e-commerce acceptance: The case of intra-European acculturation. Industrial Management \& Data Systems, 118(6), 1251-1265. doi:10.1108/ IMDS-11-2017-0509

Levy, Y., \& Ellis, T. J. (2006). A systems approach to conduct an effective literature review in support of information systems research. Informing Science, 9. doi:10.28945/479

Li, G., \& Li, N. (2019). Customs classification for cross-border e-commerce based on text-image adaptive convolutional neural network. Electronic Commerce Research, 19(4), 779-800. doi:10.1007/s10660-019-09334-X

Li, J., Yao, Y., Xu, Y., Li, J., Wei, L., \& Zhu, X. (2019). Consumer's risk perception on the Belt and Road countries: Evidence from the cross-border e-commerce. Electronic Commerce Research, 19(4), 823-840. doi:10.1007/s10660-019-09342-x

Lin, A. J., Li, E. Y., \& Lee, S. Y. (2018). Dysfunctional customer behavior in cross-border e-commerce: A Justice-affect-behavior model. Journal of Electronic Commerce Research, 19(1), 36-54.

Liu, C., \& Hong, J. (2016). Strategies and service innovations of haitao business in the Chinese market. Asia Pacific Journal of Innovation and Entrepreneurship, 10(1), 101-121. doi:10.1108/APJIE-12-2016-012

Liu, H., \& Wang, X. (2018). Study on the application of big data in accurate marketing of cross-border e-commerce in China. 2018 IEEE 3rd International Conference on Big Data Analysis (ICBDA), 24-27.

Luo, H., Liang, Y., Wu, Z., Liu, Z., Shu, B., \& Luo, Y. (2019). Research on the impact of cross-border e-commerce platform quality on customer cross-buying intention. 2019 16th International Conference on Service Systems and Service Management, ICSSSM 2019, 1-6. doi:10.1109/ICSSSM.2019.8887725

Ma, S., Chai, Y., \& Zhang, H. (2018). Rise of cross-border e-commerce exports in China. China \& World Economy, 26(3), 63-87. doi:10.1111/cwe.12243

Miao, Y., Du, R., Li, J., \& Westland, J. C. (2019). A two-sided matching model in the context of B2B export cross-border e-commerce. Electronic Commerce Research, 19(4), 841-861. doi:10.1007/s10660-019-09361-8

Mooji, M. K. de. (1998). Global marketing and Advertising, Understanding Cultural Paradoxes. Saga Publications, Inc.

Mou, J., Ren, G., Qin, C., \& Kurcz, K. (2019). Understanding the topics of export cross-border e-commerce consumers feedback: An LDA approach. Electronic Commerce Research, 19(4), 749-777. doi:10.1007/s10660019-09338-7 
Niu, B., Wang, J., Lee, C. K. M., \& Chen, L. (2019). "Product + logistics" bundling sale and co-delivery in cross-border e-commerce. Electronic Commerce Research, 19(4), 915-941. doi:10.1007/s10660-019-09379-y

Peñaloza, L. (1994). Atravesando fronteras/border crossings: A critical ethnographic exploration of the consumer acculturation of Mexican immigrants. The Journal of Consumer Research, 21(1), 32-54. doi:10.1086/209381

Polanski, P. P. (2015). Towards the single digital market for e-identification and trust services. Computer Law \& Security Review, 31(6), 773-781. doi:10.1016/j.clsr.2015.09.001

Shi, Y., Wang, T., \& Alwan, L. C. (2020). Analytics for cross-border e-commerce: Inventory risk management of an online fashion retailer. Decision Sciences, 51(6), 1-30. doi:10.1111/deci.12429

Shiau, W.-L., \& Chau, P. Y. K. (2016). Understanding behavioral intention to use a cloud computing classroom: A multiple model comparison approach. Information \& Management, 53(3), 355-365. doi:10.1016/j.im.2015.10.004

Shiau, W.-L., Sarstedt, M., \& Hair, J. F. (2019). Internet research using partial least squares structural equation modeling (PLS-SEM). Internet Research, 29(3), 398-406. doi:10.1108/IntR-10-2018-0447

Singh, N., Kumar, V., \& Baack, D. (2005). Adaptation of cultural content: Evidence from B2C e-commerce firms. European Journal of Marketing, 39(1/2), 71-86. doi:10.1108/03090560510572025

Singh, N., Zhao, H., \& Hu, X. (2003). Cultural adaptation on the web: A study of American companies' domestic and Chinese websites. Journal of Global Information Management, 11(3), 63-80. doi:10.4018/jgim.2003070104

Singh, N., Zhao, H., \& Hu, X. (2005). Analyzing the cultural content of web sites. International Marketing Review, 22(2), 129-146. doi:10.1108/02651330510593241

Song, B., Yan, W., \& Zhang, T. (2019). Cross-border e-commerce commodity risk assessment using text mining and fuzzy rule-based reasoning. Advanced Engineering Informatics, 40(January), 69-80. doi:10.1016/j. aei.2019.03.002

Standing, S., Standing, C., \& Love, P. E. D. (2010). A review of research on e-marketplaces 1997-2008. Decision Support Systems, 49(1), 41-51. doi:10.1016/j.dss.2009.12.008

Sun, T., \& Watanabe, W. C. (2018). The study of critical success factors of cross-border E-commerce freight forwarder from China to Thailand. IEEE International Conference on Industrial Engineering and Engineering Management, 1848-1852. doi:10.1109/IEEM.2017.8290211

Valarezo, Á., Pérez-Amaral, T., Garín-Muñoz, T., Herguera García, I., \& López, R. (2018). Drivers and barriers to cross-border e-commerce: Evidence from Spanish individual behavior. Telecommunications Policy, 42(6), 464-473. doi:10.1016/j.telpol.2018.03.006

Wang, F., Yang, Y., Tso, G. K. F., \& Li, Y. (2019). Analysis of launch strategy in cross-border e-Commerce market via topic modeling of consumer reviews. Electronic Commerce Research, 19(4), 863-884. doi:10.1007/ s10660-019-09368-1

Wang, L., Chai, Y., Liu, Y., \& Xu, Y. (2015). Qualitative analysis of cross-border e-commerce based on transaction costs theory. Proceedings - 12th IEEE International Conference on E-Business Engineering, ICEBE 2015, 166-172. doi:10.1109/ICEBE.2015.36

Wang, Y. (2018). Jia, F., Schoenherr, T., Gong, Y., \& Chen, L. (2019). Cross-border e-commerce firms as supply chain integrators: The management of three flows. Industrial Marketing Management, (December), 1-17. doi:10.1016/j.indmarman.2018.06.010

Wang, Yu., Wang, Y., \& Lee, S. H. (2017). The effect of cross-border e-commerce on China's international trade: An empirical study based on transaction cost analysis. Sustainability (Switzerland), 9(11), 1-13. doi:10.3390/ su9112028

Webster, J., \& Watson, R. T. (2002). Analyzing the past to prepare for the future: Writing a literature review. Management Information Systems Quarterly, xiii-xxiii.

Xiao, L., Guo, F., Yu, F., \& Liu, S. (2019). The effects of online shopping context cues on consumers' purchase intention for cross-border E-Commerce sustainability. Sustainability (Switzerland), 11(10), 1-25. doi:10.3390/ su11102777 
Yan, M. R., Tran-Danh, N., \& Hong, L. Y. (2019). Knowledge-based decision support system for improving e-business innovations and dynamic capability of IT project management. Knowledge Management Research and Practice, 17(2), 125-136. doi:10.1080/14778238.2019.1601507

Zdrenka, W., \& Kawa, A. (2016). Conception of integrator in cross-border e-commerce. LogForum, 12(1), 63-73. doi:10.17270/J.LOG.2016.1.6

Zhao, X. (2018). A study on the applications of big data in cross-border e-commerce. Proceedings - 2018 IEEE 15th International Conference on e-Business Engineering, ICEBE 2018, 280-284. doi:10.1109/ ICEBE.2018.00053

Zhong, H., Lyu, H., Zhang, S., Li, P., Zhang, Z., \& Da Xu, L. (2020). Measuring user similarity using check-ins from LBSN: A mobile recommendation approach for e-commerce and security services. Enterprise Information Systems, 14(3), 368-387. doi:10.1080/17517575.2019.1686655

Zhu, W., Mou, J., \& Benyoucef, M. (2019). Exploring purchase intention in cross-border E-commerce: A three stage model. Journal of Retailing and Consumer Services, 51(May), 320-330. doi:10.1016/j.jretconser.2019.07.004 


\section{APPENDIX A. SUMMARY OF THE SAMPLE OF ARTICLES REVIEWED BY THIS STUDY}

\section{Table 1. Summary}

\begin{tabular}{|c|c|c|c|c|c|c|}
\hline Year & $\begin{array}{l}\text { Level of } \\
\text { Analysis }\end{array}$ & Methodology & Theory & $\begin{array}{l}\text { Geographical } \\
\text { Focus }\end{array}$ & Summary & Authors \\
\hline 2014 & Individual & Empirical (survey) & Gravity model & European Union & $\begin{array}{l}\text { Explore the key drivers and } \\
\text { barriers of } \mathrm{CBeC}\end{array}$ & $\begin{array}{l}\text { Gomez- } \\
\text { Herrera et al. } \\
(2014)\end{array}$ \\
\hline 2016 & Organization & Empirical (survey) & $\begin{array}{l}\text { Post acceptance theory, } \\
\text { relational exchange } \\
\text { theory, capability } \\
\text { theory, transaction cost } \\
\text { theory }\end{array}$ & $\begin{array}{l}\text { South Korea and } \\
\text { the United States }\end{array}$ & $\begin{array}{l}\text { Study multiple dimensions } \\
\text { and evolutionary perspective } \\
\text { of e-Trade performance }\end{array}$ & $\begin{array}{l}\text { H. Kim \& } \\
\text { Lee (2016) }\end{array}$ \\
\hline 2017 & Individual & Empirical (survey) & $\begin{array}{l}\text { Consumer perceived } \\
\text { value-based model, } \\
\text { signaling theory, } \\
\text { Theory of reasoned } \\
\text { action, Theory of } \\
\text { planned behavior }\end{array}$ & Taiwan & $\begin{array}{l}\text { Study antecedents of purchase } \\
\text { intention on } \mathrm{CBeC}\end{array}$ & $\begin{array}{l}\text { S. Huang } \\
\text { \& Chang } \\
(2017)\end{array}$ \\
\hline 2017 & Individual & Empirical (survey) & $\begin{array}{l}\text { Signaling theory, } \\
\text { sociological } \\
\text { perspective }\end{array}$ & China & $\begin{array}{l}\text { Develop a conceptual } \\
\text { model that identifies a set } \\
\text { of institutional mechanisms } \\
\text { to enhance sellers' trust and } \\
\text { reduce their perceived risk }\end{array}$ & $\begin{array}{l}\text { Guo et al. } \\
(2018)\end{array}$ \\
\hline 2018 & Individual & Empirical (survey) & Justice theory & China & $\begin{array}{l}\text { Study antecedents and } \\
\text { consequences of dysfunctional } \\
\text { customer behavior in } \mathrm{CBeC}\end{array}$ & $\begin{array}{l}\text { Lin et al. } \\
(2018)\end{array}$ \\
\hline 2018 & Individual & Empirical (survey) & $\begin{array}{l}\text { Technology acceptance } \\
\text { model, theory of } \\
\text { planned behavior } \\
\text { model, motivational } \\
\text { model }\end{array}$ & European Union & $\begin{array}{l}\text { Study the effect of } \\
\text { acculturation process on } \\
\text { e-commerce acceptance }\end{array}$ & $\begin{array}{l}\text { Lacka \& Yip } \\
(2018)\end{array}$ \\
\hline 2018 & Individual & Empirical (survey) & $\begin{array}{l}\text { Theory of planned } \\
\text { behavior }\end{array}$ & South Korea & $\begin{array}{l}\text { Study consumer attitudes and } \\
\text { purchase intention on } \mathrm{CBeC}\end{array}$ & $\begin{array}{l}\text { B. Han et al. } \\
(2018)\end{array}$ \\
\hline 2018 & Individual & Empirical (survey) & $\begin{array}{l}\text { Utility maximization } \\
\text { model }\end{array}$ & European Union & $\begin{array}{l}\text { Study drivers and barriers } \\
\text { to } \mathrm{CBeC}\end{array}$ & $\begin{array}{l}\text { Valarezo et } \\
\text { al. (2018) }\end{array}$ \\
\hline 2019 & Individual & Empirical (survey) & $\begin{array}{l}\text { Hierarchy-of-effects } \\
\text { model, commitment- } \\
\text { involvement theory }\end{array}$ & China & $\begin{array}{l}\text { Study antecedents of purchase } \\
\text { intention on } \mathrm{CBeC}\end{array}$ & $\begin{array}{l}\text { Zhu et al. } \\
\text { (2019) }\end{array}$ \\
\hline 2019 & Individual & Empirical (survey) & $\begin{array}{l}\text { Stimulate-organism- } \\
\text { response theory }\end{array}$ & China & $\begin{array}{l}\text { Study the effect of } \mathrm{CBeC} \\
\text { platform quality on customer } \\
\text { cross-buying intention }\end{array}$ & $\begin{array}{l}\text { Luo et al. } \\
(2019)\end{array}$ \\
\hline 2019 & Individual & Empirical (survey) & $\begin{array}{l}\text { Signaling theory, } \\
\text { attachment theory }\end{array}$ & $\begin{array}{l}\text { Countries across } \\
\text { the world }\end{array}$ & $\begin{array}{l}\text { Study the factors affect } \\
\text { customers to shop from } \mathrm{CBeC} \\
\text { websites }\end{array}$ & $\begin{array}{l}\text { S. L. Huang } \\
\text { \& Chang } \\
(2019)\end{array}$ \\
\hline 2019 & Individual & Empirical (survey) & $\begin{array}{l}\text { Stimulate-organism- } \\
\text { response theory, cue } \\
\text { utilization theory }\end{array}$ & China & $\begin{array}{l}\text { Study antecedents of purchase } \\
\text { intention on } \mathrm{CBeC}\end{array}$ & $\begin{array}{l}\text { Xiao et al. } \\
(2019)\end{array}$ \\
\hline 2019 & Individual & Empirical (survey) & $\begin{array}{l}\text { Adaptive structuration } \\
\text { theory }\end{array}$ & South Korea & $\begin{array}{l}\text { Study antecedents of purchase } \\
\text { intention on } \mathrm{CBeC}\end{array}$ & $\begin{array}{l}\text { J. H. Han \& } \\
\text { Kim (2019) }\end{array}$ \\
\hline 2016 & Organization & $\begin{array}{l}\text { Empirical } \\
\text { (qualitative } \\
\text { interview) }\end{array}$ & Value chain model & $\begin{array}{l}\text { China and South } \\
\text { Korea }\end{array}$ & $\begin{array}{l}\text { Explore the service innovation } \\
\text { strategies and success factors } \\
\text { of } \mathrm{CBeC}\end{array}$ & $\begin{array}{l}\text { C. Liu \& } \\
\text { Hong (2016) }\end{array}$ \\
\hline 2017 & N/A & $\begin{array}{l}\text { Empirical } \\
\text { (qualitative } \\
\text { interview) }\end{array}$ & N/A & China & $\begin{array}{l}\text { Review of the publications in } \\
\text { the field of logistics in } \mathrm{CBeC}\end{array}$ & $\begin{array}{l}\text { Giuffrida et } \\
\text { al. (2017) }\end{array}$ \\
\hline
\end{tabular}


Table 1. Continued

\begin{tabular}{|c|c|c|c|c|c|c|}
\hline Year & $\begin{array}{l}\text { Level of } \\
\text { Analysis }\end{array}$ & Methodology & Theory & $\begin{array}{l}\text { Geographical } \\
\text { Focus }\end{array}$ & Summary & Authors \\
\hline 2018 & N/A & $\begin{array}{l}\text { Empirical } \\
\text { (qualitative } \\
\text { interview) }\end{array}$ & N/A & China, Thailand & $\begin{array}{l}\text { Study critical success factors } \\
\text { of } \mathrm{CBeC} \text { from China to } \\
\text { Thailand }\end{array}$ & $\begin{array}{l}\text { Sun \& } \\
\text { Watanabe } \\
(2018)\end{array}$ \\
\hline 2019 & Individual & $\begin{array}{l}\text { Empirical } \\
\text { (qualitative } \\
\text { interview) }\end{array}$ & Flow theory & $\begin{array}{l}\text { Countries across } \\
\text { the world }\end{array}$ & $\begin{array}{l}\text { Apply a mixed approach } \\
\text { of problem-based learning } \\
\text { with social media to design } \\
\text { a talents training model for } \\
\text { CBeC }\end{array}$ & $\begin{array}{l}\text { Cheng et al. } \\
\text { (2019) }\end{array}$ \\
\hline 2019 & Individual & $\begin{array}{l}\text { Empirical } \\
\text { (qualitative } \\
\text { interview) }\end{array}$ & Service-dominant logic & China & $\begin{array}{l}\text { Study how CBeCs can } \\
\text { develop supply chain service } \\
\text { capabilities that create } \\
\text { improvements in supply } \\
\text { chain relationship quality to } \\
\text { e-tailors and other platform } \\
\text { users }\end{array}$ & $\begin{array}{l}\text { Ying Wang } \\
\text { et al. (2019) }\end{array}$ \\
\hline 2019 & Product & $\begin{array}{l}\text { Empirical } \\
\text { (qualitative reviews) }\end{array}$ & N/A & China & $\begin{array}{l}\text { Apply topic modeling of } \\
\text { customer reviews to analyze } \\
\text { launch strategy in } \mathrm{CBeC}\end{array}$ & $\begin{array}{l}\text { F. Wang et } \\
\text { al. (2019) }\end{array}$ \\
\hline 2019 & Product & $\begin{array}{l}\text { Empirical } \\
\text { (qualitative reviews) }\end{array}$ & N/A & $\begin{array}{l}\text { Belt and Road } \\
\text { Initiative countries }\end{array}$ & $\begin{array}{l}\text { Study consumer's risk } \\
\text { perception in CBeC }\end{array}$ & $\begin{array}{l}\text { J. Li et al. } \\
(2019)\end{array}$ \\
\hline 2019 & Organization & $\begin{array}{l}\text { Empirical (case } \\
\text { study) }\end{array}$ & $\begin{array}{l}\text { Dynamic capabilities } \\
\text { and systems theory }\end{array}$ & Taiwan & $\begin{array}{l}\text { Propose a knowledge-based } \\
\text { management decision support } \\
\text { system by using system } \\
\text { dynamics modeling and } \\
\text { computer simulations }\end{array}$ & $\begin{array}{l}\text { Yan et al. } \\
(2019)\end{array}$ \\
\hline 2019 & Individual & $\begin{array}{l}\text { Empirical } \\
\text { (experiment) }\end{array}$ & Cue-utilization theory & China & $\begin{array}{l}\text { Study the impact of } \\
\text { geographic cues embedded in } \\
\text { CBeC websites on Chinese } \\
\text { consumers' shopping } \\
\text { experiences }\end{array}$ & $\begin{array}{l}\text { Baek et al. } \\
(2019)\end{array}$ \\
\hline 2019 & Country & $\begin{array}{l}\text { Empirical (panel } \\
\text { data) }\end{array}$ & Theory of trade gravity & $\begin{array}{l}\text { Association of } \\
\text { Southeast Asian } \\
\text { Nations (ASEAN) } \\
\text { countries }\end{array}$ & $\begin{array}{l}\text { Study the impact of country- } \\
\text { level variables such as GDP } \\
\text { and population on } \mathrm{CBeC}\end{array}$ & $\begin{array}{l}\text { He \& Wang } \\
\text { (2019) }\end{array}$ \\
\hline 2019 & Product & $\begin{array}{l}\text { Empirical } \\
\text { (predictive } \\
\text { analytics) }\end{array}$ & N/A & China & $\begin{array}{l}\text { Apply text-image adaptive } \\
\text { convolutional neural network } \\
\text { to classify CBeC customers }\end{array}$ & $\begin{array}{l}\text { G. Li \& Li } \\
(2019)\end{array}$ \\
\hline 2020 & Sale seasons & $\begin{array}{l}\text { Empirical } \\
\text { (predictive } \\
\text { analytics) }\end{array}$ & N/A & China & $\begin{array}{l}\text { Apply predictive analytics to } \\
\text { reduce inventory risk in } \mathrm{CBeC}\end{array}$ & $\begin{array}{l}\text { Shi et al. } \\
(2020)\end{array}$ \\
\hline 2016 & Organization & $\begin{array}{l}\text { Empirical } \\
\text { (secondary data) }\end{array}$ & N/A & $\begin{array}{l}\text { Countries across } \\
\text { the world }\end{array}$ & $\begin{array}{l}\text { Study the effect of early- } \\
\text { mover advantage on B2B } \\
\text { CBeC success }\end{array}$ & $\begin{array}{l}\text { Deng \& } \\
\text { Wang (2016) }\end{array}$ \\
\hline 2017 & Country & $\begin{array}{l}\text { Empirical } \\
\text { (secondary data) }\end{array}$ & $\begin{array}{l}\text { Institutional theory, } \\
\text { Resource-based view }\end{array}$ & $\begin{array}{l}\text { Countries across } \\
\text { the world }\end{array}$ & $\begin{array}{l}\text { Study logistics and regulatory } \\
\text { determinants of } \mathrm{CBeC} \text { that } \\
\text { affect the overseas direct } \\
\text { purchase }\end{array}$ & $\begin{array}{l}\text { Cho \& Lee } \\
(2017)\end{array}$ \\
\hline 2017 & Province & $\begin{array}{l}\text { Empirical } \\
\text { (secondary data) }\end{array}$ & $\begin{array}{l}\text { Comparative advantage } \\
\text { theory, International } \\
\text { trade theory }\end{array}$ & China & $\begin{array}{l}\text { Study the impact of } \mathrm{CBeC} \text { on } \\
\text { China's international trade }\end{array}$ & $\begin{array}{l}\text { Yu Wang et } \\
\text { al. (2017) }\end{array}$ \\
\hline 2019 & Individual & $\begin{array}{l}\text { Empirical (text } \\
\text { mining) }\end{array}$ & $\begin{array}{l}\text { Commitment-trust } \\
\text { theory, Valance } \\
\text { framework, DeLone } \\
\text { and McLean's } \\
\text { information systems } \\
\text { success model }\end{array}$ & China & $\begin{array}{l}\text { Study how the behavior of } \\
\text { sellers and their decision on } \\
\text { which platforms to participate } \\
\text { affect CBeC success }\end{array}$ & $\begin{array}{l}\text { Cui et al. } \\
\text { (2019) }\end{array}$ \\
\hline 2019 & Customer feedback & $\begin{array}{l}\text { Empirical (text } \\
\text { mining) }\end{array}$ & N/A & China & $\begin{array}{l}\text { Study customer e-WoM by } \\
\text { applying NLP to the customer } \\
\text { review titles }\end{array}$ & $\begin{array}{l}\text { Mou et al. } \\
(2019)\end{array}$ \\
\hline
\end{tabular}


Table 1. Continued

\begin{tabular}{|c|c|c|c|c|c|c|}
\hline Year & $\begin{array}{l}\text { Level of } \\
\text { Analysis }\end{array}$ & Methodology & Theory & $\begin{array}{l}\text { Geographical } \\
\text { Focus }\end{array}$ & Summary & Authors \\
\hline 2015 & N/A* & Conceptual & $\begin{array}{l}\text { Transaction costs } \\
\text { theory }\end{array}$ & N/A & $\begin{array}{l}\text { Provide an overview of } \\
\text { transaction costs theory and } \\
\text { its implications in the context } \\
\text { of } \mathrm{CBeC}\end{array}$ & $\begin{array}{l}\text { L. Wang et } \\
\text { al. (2015) }\end{array}$ \\
\hline 2015 & N/A & Conceptual & N/A & European Union & $\begin{array}{l}\text { Study e-identification and } \\
\text { trust services in } \mathrm{CBeC}\end{array}$ & $\begin{array}{l}\text { Polanski } \\
(2015)\end{array}$ \\
\hline 2016 & Organization & Conceptual & N/A & Poland & $\begin{array}{l}\text { Study integration of supply } \\
\text { chain in } \mathrm{CBeC}\end{array}$ & $\begin{array}{l}\text { Zdrenka \& } \\
\text { Kawa (2016) }\end{array}$ \\
\hline 2017 & Country & Conceptual & $\begin{array}{l}\text { Polycentric governance } \\
\text { or regime complexes }\end{array}$ & $\begin{array}{l}\text { China, the United } \\
\text { States }\end{array}$ & $\begin{array}{l}\text { Compare e-commerce } \\
\text { regulations in Chinese and } \\
\text { American FTAs }\end{array}$ & $\begin{array}{l}\text { J. Huang } \\
\text { (2017) }\end{array}$ \\
\hline 2017 & Individual & Conceptual & N/A & N/A & $\begin{array}{l}\text { Use Kansei engineering to } \\
\text { design logistics services for } \\
\text { CBeC }\end{array}$ & $\begin{array}{l}\text { Hsiao et al. } \\
(2017)\end{array}$ \\
\hline 2018 & Organization & Conceptual & N/A & China & $\begin{array}{l}\text { Create an index for China's } \\
\text { export e-commerce prosperity } \\
\text { and the magnitude of risk }\end{array}$ & $\begin{array}{l}\text { Ma et al. } \\
(2018)\end{array}$ \\
\hline 2018 & N/A & Conceptual & N/A & N/A & $\begin{array}{l}\text { Study the applications of } \\
\text { accurate marketing-driven } \\
\text { from big data analytics in } \\
\mathrm{CBeC}\end{array}$ & $\begin{array}{l}\text { H. Liu \& } \\
\text { Wang (2018) }\end{array}$ \\
\hline 2017 & N/A & Design & N/A & N/A & $\begin{array}{l}\text { Present a design for a novel } \\
\text { platform architecture to } \\
\text { improve the pluggability of } \\
\text { e-commerce services }\end{array}$ & $\begin{array}{l}\text { Aulkemeier } \\
\text { et al. (2017) }\end{array}$ \\
\hline 2019 & N/A & N/A & N/A & N/A & $\begin{array}{l}\text { Study sole-logistics service } \\
\text { provider strategy and dual- } \\
\text { logistics service provider } \\
\text { strategy in CBeC }\end{array}$ & $\begin{array}{l}\text { Niu et al. } \\
(2019)\end{array}$ \\
\hline 2019 & N/A & N/A & Matching theory & N/A & $\begin{array}{l}\text { Propose a two-sided matching } \\
\text { model in the context of B2B } \\
\text { CBeC }\end{array}$ & $\begin{array}{l}\text { Miao et al. } \\
(2019)\end{array}$ \\
\hline
\end{tabular}


Figure 1. Framework for the current literature on $\mathrm{CBeC}$

\begin{tabular}{|c|c|}
\hline $\begin{array}{c}\text { Drivers and Barriers Affect Success or } \\
\text { Failure of CBeC } \\
\text { (Macro Level View) } \\
\text { Cultural values and population } \\
\text { demographics }\end{array}$ & $\begin{array}{l}\text { Customers and Sellers Related Factors } \\
\text { Affect Buying Decision } \\
\text { (Micro Level View) } \\
\text { Customer past experience }\end{array}$ \\
\hline $\begin{array}{l}\text { - Home bias }(-)^{*} \\
\text { - Computer and internet skills }(+)^{\dagger} \\
\text { - Education level }(+)\end{array}$ & $\begin{array}{l}\text { - Service dissatisfaction }(-)^{*} \\
\text { - Negative sentiments about } \mathrm{CBeC}(-) \\
\text { - Service and product quality }(+) \dagger\end{array}$ \\
\hline Communication aspects & $\begin{array}{l}\text { - Service and product quality dissonance }(-) \\
\text { - Platform enduring involvement }(+)\end{array}$ \\
\hline $\begin{array}{l}\text { - Language differences (-) } \\
\text { - Cultural habits (+/-) }\end{array}$ & $C B e C$ platform and products \\
\hline Monetary costs of purchase from $C B e C$ & $\begin{array}{l}\text { - CBeC platform quality }(+) \\
\text { - Product uniqueness }(+)\end{array}$ \\
\hline $\begin{array}{l}\text { - Shipping cost }(-) \\
\text { Tariffs }(-) \\
\text { - Communication cost }(-)\end{array}$ & $\begin{array}{l}\text { - Delivery speed }(+) \\
\text { - Product integrity }(+) \\
\text { - Price incentives }(-)\end{array}$ \\
\hline Policies and control mechanisms & Customer characteristics and beliefs \\
\hline $\begin{array}{l}\text { Facilitating payments in other currencies } \\
(+) \\
\text { - Compatibility of online payment systems } \\
\text { among countries }(+) \\
\text { - Weak contract enforcements among } \\
\text { countries }(-) \\
\text { - Image of the country where } \mathrm{CBeC} \text { is } \\
\text { located }(+) \\
\text { - IT infrastructures }(+)\end{array}$ & $\begin{array}{l}\text { - Attitude toward e-commerce }(+) \\
\text { - Perceived behavioral control }(+) \\
\text { - Platform situational involvement }(+) \\
\text { - Trust in CBeC seller }(+) \\
\text { - Age }(-) \\
\text { - Gender-males vs females }(+) \\
\text { - Education }(+) \\
\text { - Computer and internet skills }(+)\end{array}$ \\
\hline $\begin{array}{l}\text { 8A (-): When } \mathrm{A} \text { decreases the chance of } \mathrm{CBeC} \\
\text { success decreases } \\
\dagger \mathrm{A}(+) \text { : When } \mathrm{A} \text { increases the chance of } \mathrm{CBeC} \\
\text { success increases }\end{array}$ & $\begin{array}{l}\text { 'A (-): When A decreases the chance that a } \\
\text { customer makes the purchase decision decreases } \\
\dagger \mathrm{A}(+) \text { : When } \mathrm{A} \text { increases the chance that a } \\
\text { customer makes the purchase decision increases }\end{array}$ \\
\hline
\end{tabular}

Bidyut Hazarika $(P h D)$ is an Assistant Professor in the Business Information Systems Department at the Haworth College of Business, Western Michigan University. His research have appeared in journals such as Behaviour and Information Technology, International Journal of Business Information Systems, International Journal of E-Business Research, Journal of Global Information Management, International Journal of Business and Systems Research and Issues in Information Systems. His research interests include analytics, e-commerce and IT strategy. In addition, he has published multiple book chapters. Bidyut holds a Bachelor of Engineering, MBA, and a PhD.

Reza Mousavi is an Assistant Professor of Business Information Systems at Western Michigan University, USA. He earned his Ph.D. in Business Computer Information Systems from University of North Texas, USA. He also received a degree of MBA from Sharif University of Technology, Iran and a bachelor of computer science from University of Isfahan, Iran. His research interests are social media, e-commerce, information assurance, and business and social media analytics. He has published his research in Decision Support Systems, Journal of Computer Information Systems, and Behavior and Information Technology. 